\title{
MENELISIK TERTIB HUKUM PERATURAN PEMERINTAH PENGGANTI UNDANG-UNDANG MELALUI VALIDITAS SUATU NORMA HUKUM
}

\author{
Ricca Anggraeni ${ }^{* 1}$, Indah Mutiara Sari ${ }^{2}$ \\ ${ }^{1}$ Fakultas Hukum Universitas Pancasila \\ ${ }^{2}$ Program Magister IImu Hukum Universitas Indonesia \\ riccaanggraeni@univpancasila.ac.id
}

\begin{abstract}
The struggle of tendency in forming a regulation is not the new problem in the world of statutory regulations. Community-oriented law is a dream that must be immediately realized by Indonesian government. But unfortunately, this is still far from being realized if we look at the policies issued at this time. Like Government Regulation in Lie of Law Number 1 Year 2020 concerning State Financial Policy and Financial System Stability for Handling Corona Virus Disease 2019 (COVID-19) and / or In Order to Face Threats that Endanger the National Economy and / or Financial System Stability, since stipulation of reaping various negative responses which are dominated by public suspicion that through this regulation, the government accommodates pragmatic interests more than community needs. The existence of this regulation then questioned as to its validity as a legal norm that is issued in a short time by reason of coercive circumstances. The People's Representative Council is then demanded to become the supporting institution to keep it in line with the concept of the laws and regulations in Indonesia.
\end{abstract}

Keywords: Government Regulation in Lie of Law; Validity; Coercive Circumstances

\begin{abstract}
Abstrak
Pergulatan tendensi dalam membentuk suatu peraturan bukanlah hal baru dalam dunia peraturan perundang-undangan. Hukum yang berorientasi pada masyarakat adalah mimpi yang harus segera diwujudkan oleh pemerintah Indonesia. Namun sayangnya, hal ini seperti masih jauh untuk diwujudkan jika melihat pada kebijakan-kebijakan yang dikeluarkan pada saat ini. Seperti Peraturan Pemerintah Pengganti Undang-Undang (Perppu) Nomor 1 Tahun 2020 tentang Kebijakan Keuangan Negara dan Stabilitas Sistem Keuangan Untuk Penanganan Pandemi Corona Virus Disease 2019 (COVID- 19) dan/atau Dalam Rangka Menghadapi Ancaman yang Membahayakan Perekonomian Nasional dan/atau Stabilitas Sistem Keuangan yang sejak ditetapkannya menuai beragam tanggapan negatif yang didominasi oleh kecurigaan masyarakat bahwa melalui instrumen Perppu ini, pemerintah lebih mengakomodasi kepentingan pragmatis dibanding kebutuhan masyarakat. Keberadaan Perppu ini kemudian dipersoalkan validitasnya sebagai sebuah norma hukum yang dikeluarkan dalam waktu singkat dengan alasan keadaan yang memaksa. DPR kemudian dituntut untuk menjadi lembaga pengampu Perppu agar tetap sejalan dengan konsep peraturan perundang-undangan di Indonesia.
\end{abstract}

Kata Kunci: Peraturan Pemerintah Pengganti Undang-Undang; Validitas; Norma Hukum; Keadaan yang Memaksa 


\section{A. Pendahuluan}

Pandemi Covid-19 yang dihadapi dunia termasuk Indonesia telah membuat Pemerintah "kalang kabut". ${ }^{1}$ Hal ini terjadi karena Indonesia tidak menyiapkan mitigasi risiko saat pandemi, yang didalamnya menjamin ketersediaan data dan informasi, ketangguhan ekonomi, serta infrastruktur kesehatan. ${ }^{2}$ Ini akhirnya menyebabkan Pemerintah mengeluarkan sepaket kebijakan, baik dalam bentuk tindakan maupun peraturan perundang-undangan untuk memitigasi risiko akibat pandemi, termasuk mencegah perluasan Pandemi dan mengatasi dampak Pandemi terhadap berbagai aspek kehidupan.

Salah satu kebijakan dalam bentuk peraturan perundang-undangan yang ditetapkan oleh Pemerintah ialah Peraturan Pemerintah Pengganti Undang-Undang (Perppu) Nomor Nomor 1 Tahun 2020 tentang Kebijakan Keuangan Negara Dan Stabilitas Sistem Keuangan Untuk Penanganan Pandemi Corona Virus Disease 2019 (COVID- 19) dan/atau Dalam Rangka Menghadapi Ancaman Yang Membahayakan Perekonomian Nasional dan/atau Stabilitas Sistem Keuangan. Sejak ditetapkan, Perppu ini langsung menuai kontra dan kritikan dari berbagai pihak. Itu disebabkan tidak lain dari muatan Perppu yang dalam sudut pandang berbagai kalangan hanya menguntungkan kaum pengusaha dan pejabat yang diberikan legitimasi untuk melakukan tindakan sebagaimana ditentukan melalui Perpu Nomor 1/2020. Kejanggalan juga dianggap menguat di dalam materi muatan Perpu Nomor 1/2020 ini, sehingga perlu dikritisi, agar ketika menjadi Undang-Undang tidak semata-mata menjadi sistem yang merusak tatanan sistem norma hukum dan politik hukum di Indonesia.

Sebagai Perpu, sebagaimana ditentukan melalui ketentuan Pasal 22 Undang-Undang Dasar Negara Republik Indonesia Tahun 1945, ditetapkan oleh Presiden dalam hal ihwal kegentingan yang memaksa, dan harus mendapat persetujuan Dewan Perwakilan Rakyat (DPR) pada persidangan yang berikut. Jika tidak, maka peraturan pemerintah sebagai pengganti undang-undang itu harus dicabut. Artinya, Perpu merupakan peraturan pemerintah yang ditetapkan sebagai pengganti Undang-Undang oleh Presiden dalam hal ihwal kegentingan yang memaksa. Selain itu, Perpu memiliki keberlakuan yang sementara, karena di persidangan yang berikut harus diajukan ke DPR untuk mendapatkan persetujuannya. Dengan demikian, DPR dalam hal ini berfungsi sebagai legislative review bagi Peraturan Pemerintah yang ditetapkan sebagai pengganti undang-undang oleh Presiden.

\footnotetext{
1 Istilah ini digunakan dalam artikel di Kompas.com, yang ditulis oleh Deti Mega Purnamasari, Ed. Kristian Erdianto, "Pemerintah Dinilai Kalang Kabut dalam Menghadapi Pandemi Covid-19," pada https://nasional.kompas.com/read/2020/04/09/19421111/pemerintah-dinilai-kalang-kabut-dalammenghadapi-pandemi-covid-19.
} 
Menariknya dalam kajian ini ialah soal Perppu-bukan hanya Perppu Nomor 1 Tahun 2020yang ditetapkan oleh Presiden dalam hal untuk mengatasi kegentingan yang memaksa. Ini mengindikasikan bahwa Perppu tidak dibentuk berdasarkan suatu perencanaan yang dituangkan dalam Program Legislasi Nasional. Sedangkan, ketika Perppu itu sudah ditetapkan dan disahkan oleh Presiden, secara langsung, Perppu itu memiliki eksistensi dan keberlakuan yang mengikat hukum. Mengkhawatirkan memang, jika Perppu itu dibentuk atas dasar kondisional kegentingan yang memaksa. Presiden harus secara cepat mengambil keputusan untuk menetapkan Perppu yang dianggap mampu untuk mengatasi permasalahan yang membutuhkan solusi melalui ketentuan Undang-Undang. Dengan demikian, tertib hukum atas Perppu melalui validitas suatu norma hukum perlu ditelisik, dalam hal ini akan dilakukan oleh DPR sebagai pengampu untuk melakukan legislative review atas muatan Perppu. Tulisan ini menggagas pentingnya menelisik tertib hukum Perppu melalui validitas suatu norma hukum seperti yang dikemukakan oleh Hans Kelsen.

\section{B. Pembahasan}

\section{Perppu Secara Normatif dalam Sistem Ketatanegaraan Republik Indonesia}

Perppu adalah salah satu instrumen legal dalam pembentukan payung hukum di Indonesia yang hak pembentukannya ada pada Presiden. Ini berdasarkan Pasal 22 UUD 1945 ayat (1), yang menyatakan bahwa "dalam hal ikhwal kegentingan yang memaksa, Presiden berhak menetapkan Peraturan Pemerintah sebagai Pengganti Undang-Undang." Pasal 22 ayat (2) UUD NRI Tahun 1945 nya menentukan bahwa Perppu yang telah dibentuk dan ditetapkan oleh Presiden kemudian harus mendapatkan persetujuan DPR dalam persidangan berikutnya, dan jika tidak mendapat persetujuan maka peraturan pemerintah itu dapat dicabut secara legal.

Secara hierarki, Perppu memiliki kekuatan hukum yang sama dengan Undang-Undang sebagaimana ditentukan oleh Pasal 7 Undang-Undang Nomor 12 Tahun 2011 tentang Pembentukan Peraturan Perundang-undangan. Kendati demikian, Maria Farida menuliskan dalam 2 (dua) bukunya yang berbeda bahwa, tidak selamanya Perppu memiliki kedudukan hukum yang sama dengan undang-undang, hal ini dikarenakan penetapan Perppu dalam keadaan yang genting ini belum mendapatkan persetujuan dari DPR selaku lembaga legislatif. ${ }^{3}$ Kemudian pada buku lainnya yang masih membahas seputar peraturan perundang-undangan, Maria Farida juga menorehkan bahwa dalam keadaan normal undang-undang selalu dibentuk oleh DPR dengan persetujuan Presiden serta disahkan oleh Presiden, sedangkan Perpu

3 Maria Farida Indrati, IImu Perundang-undangan Dasar-Dasar dan Pembentukannya. (Yogyakarta:Kanisisus, 1998), hlm 96. 
dibentuk oleh Presiden tanpa persetujuan DPR karena adanya "suatu hal ihwal kegentingan yang memaksa."

Dari ketentuan dan yang dituliskan oleh Maria Farida, apabila ditarik konklusi konkrit mengenai kedudukan hukum Perppu dan undang-undang, maka akan didapati bahwa keduanya memang memiliki kedudukan yang sama, namun Perppu juga bisa memiliki kedudukan hukum yang lebih rendah dari undang-undang dikarenakan kondisi pembentukan yang berada pada keadaan genting, dan juga pembentukan awalnya yang tidak melibatkan otoritas lembaga legislatif.

Hal inilah yang akhirnya juga menjadi salah satu kekhawatiran tentang Perppu yang memiliki proses pembentukan norma yang singkat karena didasarkan pada keadaan-keadaan yang genting, dan selalu melewati proses pembentukan yang relatif mudah dan sederhana jika dibandingkan dengan proses pembentukan undang-undang, namun memiliki kedudukan hukum yang sama kuatnya dengan undang-undang.

Proses pembentukan Perppu yang dinilai jauh lebih singkat dari proses pembentukan undang-undang disebabkan oleh timbulnya hal ikhwal kegentingan memaksa, yang akhirnya harus diredam dan diatasi dengan dibentuknya suatu payung hukum baru dengan waktu sesingkat-singkatnya. Namun, di awal kehadirannya, nomenklatur "hal ikhwal kegentingan yang memaksa" sering mengundang mosi perdebatan mengenai makna penafsirannya. Hal ikhwal kegentingan yang memaksa oleh beberapa penafsirnya dianggap sebagai suatu celah bagi pembentuknya untuk mengakomodasi kepentingan-kepentingan tertentu yang tidak menjadi kepentingan bersama.

Lahirnya Putusan Mahkamah Konstitusi (MK) Nomor 138/PUU-VII/2009 tanggal 8 Februari 2010 Perihal Pengujian Perppu Nomor 4 Tahun 2009 tentang Komisi Pemberantasan Tindak Pidana Korupsi menjadi awal baru dari penentuan dimensi hal ihwal kegentingan yang memaksa dengan indikator yang lebih objektif. Dalam ketentuan Putusan MK tersebut telah ditetapkan 3 (tiga) syarat adanya kegentingan yang memaksa seperti halnya yang dimaksud dalam Pasal 22 ayat (1) UUD 1945. Pertama, adanya keadaan yaitu kebutuhan mendesak untuk menyelesaikan masalah hukum secara cepat berdasarkan undang-undang. Kedua, undang-undang yang dibutuhkan tersebut belum ada sehingga terjadi kekosongan hukum, atau ada undang-undang yang tidak memadai. Ketiga, Kekosongan hukum tersebut tidak dapat diatasi dengan cara membuat Undang-Undang secara prosedur biasa karena akan memerlukan

4 Maria Farida Indrati, IImu Perundang-undangan Proses dan Teknik Pembentukannya. (Yogyakarta:Kanisisus, 2007), hlm 80. 
waktu yang cukup lama sedangkan keadaan yang mendesak tersebut perlu kepastian untuk diselesaikan. $^{5}$

Selain daripada kedudukan yang sama secara hierarki antara Perppu dengan undangundang, materi muatan keduanya juga dinyatakan sama melalui Pasal 11 Undang-Undang Nomor 12 Tahun 2011 tentang Pembentukan Peraturan Perundang-undangan, sehingga konsekuensi logisnya adalah terhadap norma yang terdapat dalam Perpu tersebut, Mahkamah Konstitusi dapat menguji Perpu terhadap UUD $1945 .{ }^{6}$

Maria Farida menulis dalam bukunya bahwa, penetapan Perppu dengan alasan kegentingan yang memaksa adalah hak subyektifitas Presiden. Lebih lanjut juga dijelaskan bahwa "Hak Presiden untuk menetapkan Perppu itu hanya dilakukan/dilaksanakan dalam hal ikhwal kegentingan yang memaksa. Dalam penjelasan Pasal 22 UUD 1945 dikatakan bahwa Pasal ini mengenai "noodverordeningsrecht" atau "hak Presiden untuk mengatur dalam kegentingan yang memaksa". Pengertian "hal ikhwal kegentingan yang memaksa" tersebut tidak selalu ada hubungannya dengan keadaan bahaya, tetapi cukup kiranya apabila menurut keyakinan Presiden terdapat keadaan mendesak, dan keadaan itu perlu segera diatur dengan peraturan yang mempunyai derajat yang sama dengan undang-undang. Pengaturan terhadap keadaan tersebut tidak dapat ditangguhkan sampai adanya sidang DPR yang akan membicarakan pengaturan terkait keadaan tersebut. ${ }^{7}$

\section{Validitas Suatu Norma Hukum Menurut Hans Kelsen}

Validitas seringkali ditangkap salah makna dengan efektivitas, padahal antara validitas dan efektivitas berbeda. Namun, masih saja ada yang menyamakan bahwa validitas itu sama dengan efektivitas. Merujuk secara konsep, validitas itu dibangun oleh efektivitas dari keseluruhan tertib hukum. ${ }^{8}$ Artinya, efektivitas menjadi prasyarat bagi validitas, atau menjadi legitimasi bagi setiap norma hukum yang berada di dalam tertib hukum.

Dari jabaran tersebut ingin dikatakan bahwa validitas hukum itu sangat bergantung pada efektivitas norma hukum dalam suatu tertib hukum. Itu artinya, validitas sangat bergantung pada efektivitas suatu norma dasar dalam hal ini ialah teori norma hukum menurut Hans Kelsen yaitu Grundnorm. Namun, suatu tertib hukum tidak akan kehilangan validitasnya apabila tidak

5 Lihat Putusan Mahkamah Konstitusi (MK) Nomor 138/PUU-VII/2009 tanggal 8 Februari 2010 perihal Pengujian Perppu Nomor 4 Tahun 2009 tentang Komisi Pemberantasan Tindak Pidana Korupsi.

6 Achmad Edi Subiyanto, "Menguji Konstitusionalitas Peraturan Pemerintah Pengganti UndangUndang", Lex Jurnalica (Vol. 11, No 1, April 2014).

7 Maria Farida Indrati, Ilmu Perundang-undangan: Jenis, Fungsi dan Hierarki, (Yogyakarta: Kanisius, 2007), hlm. 192.

8 Atip Latipulhayat, "Hans Kelsen", Padjajaran Jurnal Ilmu Hukum, Vol. 1, Nomor 1, Tahun 2014, hlm. 204 
berjalan efektif. Suatu tertib hukum akan kehilangan validitasnya, apabila norma hukum di dalam tertib hukum itu sama sekali tidak pernah dapat dilaksanakan.

Validitas suatu norma hukum dapat ditentukan selain oleh kefektifan juga oleh suatu tertib hukum. Artinya, norma hukum yang valid harus merupakan bagian dari sistem norma. Jadi, validitas norma akan membentuk suatu hieraki norma hukum yang disebut dengan stufenttheory. Hal ini dikarenakan, suatu norma yang valid harus dinyatakan valid dan tidak bertentangan dengan norma yang di atasnya. Begitu seterusnya sampai dengan norma tertinggi yang disebut dengan Grundnorm. Dengan validitas ini, Hans Kelsen ingin menggambarkan bahwa suatu tertib hukum merupakan suatu sistem norma hukum yang saling terkait satu sama lain, dan kesemuanya akan berujung pada suatu norma yang tertinggi yang tidak berdasar dan bersumber pada norma lain yang disebut dengan grundnorm. Dengan demikian, semua norma hukum di dalam suatu tertib hukum merupakan milik satu tata aturan hukum yang sama karena validitas. ${ }^{9}$

Validitas tersebut menunjukkan bahwa keberlakuan suatu norma dapat diuji dengan mengguanakan norma lainnya, dan ini membuat suatu pemahaman yang disebut dengan positivisme hukum. Pemahaman ini kemudian melahirkan suatu tujuan hukum yaitu kepastian. ${ }^{10}$ Apabila sudah sampai pada norma yang tertinggi, maka sesungguhnya menurut Kelsen, validitasnya sudah tidak dapat dipertanyakan lagi. Hal ini dikarenakan pembentukan norma dasar atau Grundnorm ialah kepada pendasaran wewenang politik yang pada akhirnya tidak dapat didasarkan pada penetapan hukum positif. ${ }^{11}$ Pendasaran pada wewenang politik dalam tatanan tertib hukum di Indonesia dapat ditemukan pada suatu basis kehendak yang berhasil memaksakan diri sebagai penguasa yang harus diakui di dalam perumusan suatu norma yang akhirnya diakui sebagai sumber dari segala sumber hukum. ${ }^{12}$ Oleh karena itu, untuk menentukan suatu validitas norma, juga diperlukan suatu kesepakatan.

Apabila mengombinasi dengan yang dinyatakan oleh Hans Kelsen dalam bukunya yang kemudian diterjemahkan oleh Jimly Asshiddiqie dan M. Ali Safa'at, maka berdasarkan validitas suatu norma, hukum merupakan suatu tertib tata aturan (order) sebagai suatu sistem aturanaturan (rules) yang mengatur tentang prilaku manusia. Dengan demikian, hukum harus menunjuk pada seperangkat aturan (rules) yang memiliki satu kesatuan sebagai suatu sistem.

9 Mhd. Yusrizal Adi Syaputra, "Kajian Yuridis Terhadap Penegasan Hierarki Peraturan Perundangundangan di Indonesia Dalam Perspektif Stufen Theorie," Mercatoria, Vol. 9. Nomor 2, Desember 2016, HIm. 99

10 Vidya Prahassacitta, "Pandangan Positivisme Hukum," diakses melalui https://businesslaw.binus.ac.id/2019/08/25/pandangan-positivisme-hukum/, pada tanggal 19 Mei 2020.

11 Jaka Susila, "Hukum Sebagai Paradigma Fakta Sosial", Prosiding Seminar Nasional, diakses melalui https://publikasiilmiah.ums.ac.id/bitstream/handle/11617/5706/29. Jaka\%20Susila.pdf?sequence=1\&is

$12 \frac{\text { Allowed }}{\text { Ibid. }}$ 
Dengan hal seperti ini, sebagai konsekuensinya, ialah tidak mungkin memahami hukum, jika tidak memperhatikan seperangkat aturan dalam satu kesatuan sistem tertib hukum. ${ }^{13}$ Oleh karena itu, di dalam suatu tertib hukum, menakar validitas suatu norma hukum tidak berhenti hanya berdasarkan pada norma yang lebih tinggi dan dibentuk oleh lembaga yang berwenang serta melalui kesepakatan, melainkan ini mengandung suatu hal tertentu, yang disebut dengan harmonisasi.

Validitas suatu norma hukum tentu ditentukan oleh keberlakuan dari norma lain yang lebih tinggi. Pemberlakuan ini menunjukkan bahwa tidak boleh ada pertentangan antara norma yang lebih rendah dengan norma yang lebih tinggi, karena norma yang lebih tinggi akan menjadi batu uji bagi norma yang lebih rendah. Oleh karena itu, untuk dapat menemukan konsistensi, koherensi dan korespondensi antara norma yang lebih rendah dengan norma yang lebih tinggi, perlu dilakukan suatu harmonisasi.

\section{Tertib Hukum Perppu Melalui Validitas Suatu Norma Hukum Menurut Hans Kelsen}

Melalui Pasal 2 UU Nomor 12 Tahun 2011 diketahui bahwa Pancasila merupakan sumber dari segala sumber hukum negara. Sebelumnya, apabila menggunakan pendekatan sejarah, di dalam Ketetapan MPRS Nomor XX/MPRS/1966 dinyatakan bahwa Pancasila merupakan sumber tertib hukum Indonesia. Secara kritis sesungguhnya ingin dinyatakan bahwa maksud tertib hukum di Indonesia bukan hanya menyoal pada peraturan perundang-undangan -an sichtetapi juga pada keseluruhan kaidah hukum di Indonesia, termasuk produk yudikatif berupa putusan-putusan hakim.

Secara normatif, misalnya ketika hanya merujuk pada UU Nomor 12 Tahun 2011, nalar fikir hanya terbawa pada arus positivisme, bahwa Pancasila hanya untuk pembentukan jenis norma hukum yang berada di dalam hierarki. Padahal merujuk pada pemahaman tertib hukum, norma hukum bukan hanya berupa peraturan perundang-undangan tetapi juga berupa keputusan yang bersifat beschikking, bahkan termasuk putusan. Pemahaman ini sesuai dengan yang dinyatakan oleh Jimly Asshiddiqie sebagaimana dikutip oleh Muhtadi dalam sebuah artikel, bahwa tertib hukum itu menunjukkan pemahaman yang lebih luas, bukan hanya mencakup berbagai putusan legislatif dan eksekutif yang dapat dijadikan sumber hukum, tetapi mencakup pula putusan-putusan pengadilan dalam lingkungan kekuasaan judikatif. ${ }^{14}$

Menyisir pada soalan validitasnya, berdasarkan uraian di atas, pemahaman yang hinggap ialah bahwa Pancasila menjadi tumpuan dari keberlakuan seluruh norma hukum di Indonesia.

13 Ida Keumala Jeumpa, "Contempt Of Court: Suatu Perbandingan Antara Berbagai Sistem Hukum," Kanun Jurnal IImu Hukum No. 62, Th. XVI (April, 2014), HIm. 153-154.

14 Jimly Asshiddiqie dalam Muhtadi, "Penerapan Teori Hans Kelsen Dalam Tertib Hukum Indonesia", Fiat Justitia Jurnal IImu Hukum Vol. 5 No. 2 September-Desember 2012, hlm. 296. 
Dapat dikatakan, Pancasila menjadi satu-satunya batu uji bagi tertib hukum dalam suatu sistem norma hukum di Indonesia, bahkan sampai pada keberlakuan kaidah individuil sekalipun. Dengan demikian, sudah suatu keharusan, dalam penyusunan kaidah formil, mengkonsistenkan, mengkoherensikan dan mengkorespondenkan materi muatan suatu kaidah hukum yang termasuk dalam sistem hukum Indonesia dengan nilai-nilai Pancasila dan UndangUndang Dasar NRI Tahun 1945, karena Undang-Undang Dasar NRI Tahun 1945 menjadi dasar tertib hukum bagi peraturan perundang-undangan di bawahnya.

Hal tersebut menjadi penanda penting, karena validitas sangat bergantung pada efektivitas suatu norma dasar. Bahwa suatu norma yang valid harus dinyatakan valid dan tidak bertentangan dengan norma yang di atasnya. Begitu seterusnya sampai dengan norma tertinggi yang disebut dengan Grundnorm. Oleh karena itu, tertib hukum merupakan suatu sistem norma hukum yang saling terkait, dan akan berujung pada suatu norma yang tertinggi yang bersifat pre-supposed yang disebut dengan grundnorm. Dengan kata lain, di dalam suatu tertib hukum terdapat satu tata aturan hukum yang sama karena validitas. Selain itu, pendasaran wewenang politik dalam pembentukan tatanan tertib hukum di Indonesia dapat ditemukan. Ini yang dikatakan sebagai suatu basis kehendak yang harus diakui di dalam perumusan suatu norma hukum, dan ini terdapat dalam proses pembahasan. Oleh karena itu, untuk menentukan suatu validitas norma, juga diperlukan suatu kesepakatan.

Sebagai suatu tatanan sistem, untuk menentukan validitas suatu norma juga memerlukan pengkajian norma-norma hukum terdapat dalam suatu tata aturan sebagai suatu sistem. Kinerja tertib hukum harus diperhatikan, sehingga norma hukum yang akan dibuat akan menjadi sub sistem norma yang saling mendukung tertib hukum satu sama lain. Artinya, pertentangan sangat tidak dimungkinkan dalam pembentukan norma hukum di suatu tatanan tertib hukum.

Menarik di dalam suatu pembentukan Perppu. Seperti diketahui bahwa Perppu merupakan suatu jenis peraturan perundang-undangan yang dibentuk oleh Presiden untuk mengatasi hal ikhwal kegentingan yang memaksa. Situasi kegentingan yang memaksa ini mendorong Presiden mengeluarkan suatu peraturan untuk mengatasi permasalahan yang dihadapi secara nasional, dan permasalahan itu hanya dapat diatasi hanya dengan menggunakan peraturan dalam jenis Undang-Undang.

Berdasarkan Pasal 22 UUD NRI Tahun 1945, Perppu secara hakikat merupakan peraturan pemerintah yang difungsikan sebagai pengganti dari Undang-Undang. Konsekuesninya secara formil, dalam keberlakuannya, Perppu harus diajukan ke DPR untuk mendapatkan persetujuan soal materinya yang tentu harus memenuhi kebutuhan dan menyelesaikan permasalahan yang timbul dalam hal ikhwal kegentingan yang memaksa itu. DPR harus secara jernih menakar hal ikhwal kegentingan yang memaksa itu di dalam proses 
pembahasan sebagai reviewnya agar itu tidak bertukar guling dengan kepentingan-kepentingan yang diterjemahkan sebagai kegentingan yang memaksa oleh hak subyektifitasnya Presiden. Sebagai "noodverordeningsrecht" atau "hak Presiden untuk mengatur dalam kegentingan yang memaksa", tentu "hal ikhwal kegentingan yang memaksa" ini tidak selalu ada hubungannya dengan keadaan bahaya, tetapi cukup diserahkan kepada keyakinan Presiden bahwa secara nasional terdapat keadaan mendesak, dan itu perlu segera diatur dengan peraturan yang mempunyai derajat yang sama dengan undang-undang.

Indikasi segera di dalam pembentukan Perppu membuat Perppu tidak dapat dibentuk sesuai dengan proses pembentukan peraturan perundang-undangan sebagaimana ditentukan melalui Pasal 1 angka 1 UU Nomor 12 Tahun 2011. Pembentukan Perppu tentu tidak dapat direncanakan di dalam sebuah Program Legislasi Nasional, tidak dapat dituangkan dalam suatu kajian atau penelitian yang disebut dengan Naskah Akademik. Presiden dalam membentuk Perppu menugaskan menteri yang tugas dan tanggung jawabnya sesuai dengan materi yang akan diatur dalam Perppu untuk menyusun materi perppu. Setelah itu, barulah disampaikan kepada Presiden untuk ditetapkan.

Menariknya, Perppu baru akan diharmonisasikan, dikonsepsikan dan dibulatkan apabila Perppu itu akan diajukan kepada DPR untuk dibahas menjadi Undang-Undang. Ini membuat kekhawatiran, seperti yang sudah disampaikan diawal bahwa materi Perppu dapat out of track dari tertib hukum Indonesia. Kesegeraan dari ditetapkannya Perpu sangat membuka peluang risiko bagi Perppu untuk tidak berada dalam suatu tata aturan hukum yang sama dengan sumber hukum pembentuknya. Sebagai jenis peraturan perundang-undangan yang hierarkinya sama dengan undang-undang dan difungsikan sebagai pengganti undang-undang, Perppu dalam pembentukannya harus berdasar dan bersumber pada Undang-Undang Dasar NRI Tahun 1945. Dengan demikian, perppu pun harus tetap mencerminkan nilai-nilai Pancasila di dalam materi muatannya.

Sebagai suatu norma hukum dalam bentuk yang formal, Perppu tentu setelah ditetapkan dan disahkan oleh Presiden akan memiliki validitas. Validitas dari Perppu juga akan ditentukan oleh Presiden sebagai pembentuknya dan norma hukum di atasnya yaitu Undang-Undang Dasar Negara Republik Indonesia Tahun 1945. Sesungguhnya menjadi penting untuk melakukan sinkronisasi atas rancangan materi muatan Perppu dengan ketentuan UUD NRI Tahun 1945, sehingga pembentuk yakin bahwa tidak ada muatan yang out of track dan context dari norma hukum di atas yang menjadi sumber formal bagi perppu. Dengan kata lain, tidak ada pertentangan dengan norma-norma di atasnya, mengingat syarat kondisional pembentukan Perppu ini berisiko untuk ditunggangi oleh kepentingan-kepentingan sesaat yang berselubung dengan kegentingan yang memaksa. 
Melihat secara normatif pada proses pembentukannya, sesungguhnya validitas Perppu ini diperlukan pengujian, sehingga tidak semata-mata menjadi sah dan berlaku sebagai suatu tertib hukum dalam tatanan norma hukum di Indonesia. Pengajuan ke DPR untuk dilakukan pembahasan agar terdapat persetujuan menjadi critical point selanjutnya dari validitas Perppu untuk menjadi Undang-Undang. Penting sesungguhnya bagi DPR sebagai pemilik wewenang secara politik untuk mengambil kesepakatan atas Perppu menjadi Undang-Undang, dalam hal mengetahui muatan dari Perppu dan koherensi, korespondesi serta konsistensinya dengan UUD NRI Tahun 1945 dan Pancasila sebagai sumber tertib hukum di Indonesia.

\section{Simpulan}

Penelisikan validitas Perppu dalam tertib hukum Indonesia harusnya dilakukan oleh DPR sebagai pengampu untuk melakukan pembahasan yang selanjutnya ialah menentukan persetujuan atas muatan Perppu. Sebagai suatu norma, setelah Perppu ditetapkan dan disahkan oleh Presiden akan memiliki validitas. Validitas dari Perppu tentu akan bergantung pada norma hukum di atasnya yaitu Undang-Undang Dasar Negara Republik Indonesia Tahun 1945, sehingga menjadi penting untuk melakukan sinkronisasi atas rancangan materi muatan Perppu dengan ketentuan UUD NRI Tahun 1945, sehingga pembentuk yakin bahwa muatan Perppu on the track dengan norma hukum di atas yang menjadi sumber formal bagi perppu.

Sesungguhnya validitas Perppu ini juga diperlukan pengujian, sehingga tidak sematamata menjadi sah dan berlaku sebagai suatu tertib hukum dalam tatanan norma hukum di Indonesia. Pengajuan ke DPR untuk dilakukan pembahasan menjadi critical point bagi validitas Perppu untuk menjadi Undang-Undang. Penting bagi DPR sebagai pemilik wewenang secara politik untuk mengambil kesepakatan atas Perppu menjadi Undang-Undang, dalam hal mengetahui muatan dari Perppu dan koherensi, korespondesi serta konsistensinya dengan UUD NRI Tahun 1945 dan Pancasila sebagai sumber tertib hukum di Indonesia.

\section{DAFTAR PUSTAKA}

Erdianto, Ed. Kristian. "Pemerintah Dinilai Kalang Kabut dalam Menghadapi Pandemi Covid19." https://nasional.kompas.com/read/2020/04/09/19421111/pemerintah-dinilai-kalangkabut-dalam-menghadapi-pandemi-covid-19.

Indrati, Maria Farida. 1998. Ilmu Perundang-undangan Dasar-Dasar dan Pembentukannya. Yogyakarta:Kanisius.

Indrati, Maria Farida. 2007. Ilmu Perundang-undangan Proses dan Teknik Pembentukannya. Yogyakarta:Kanisisus.

Indrati, Maria Farida. 2007. IImu Perundang-undangan: Jenis, Fungsi dan Hierarki. Yogyakarta: Kanisius. 
Jeumpa, Ida Keumala. 2014. "Contempt Of Court: Suatu Perbandingan Antara Berbagai Sistem Hukum.” Kanun Jurnal IImu Hukum No. 62. Th. XVI .April.

Latipulhayat, Atip. 2014. “Hans Kelsen”, Padjajaran Jurnal IImu Hukum. Vol. 1. Nomor 1.

Mahkamah Konstitusi. Putusan Mahkamah Konstitusi (MK) Nomor 138/PUU-VII/2009 tanggal 8 Februari 2010 perihal Pengujian Perppu Nomor 4 Tahun 2009 tentang Komisi Pemberantasan Tindak Pidana Korupsi.

Muhtadi. 2012. "Penerapan Teori Hans Kelsen Dalam Tertib Hukum Indonesia". Fiat Justitia Jurnal Ilmu Hukum. Vol. 5 No. 2 September-Desember.

Prahassacitta, Vidya. "Pandangan Positivisme Hukum." diakses melalui https://businesslaw.binus.ac.id/2019/08/25/pandangan-positivisme-hukum/. pada tanggal 19 Mei 2020.

Subiyanto, Achmad Edi. 2014. "Menguji Konstitusionalitas Peraturan Pemerintah Pengganti Undang-Undang", Lex Jurnalica. Vol. 11. No 1. April.

Syaputra, Mhd. Yusrizal Adi. 2016. "Kajian Yuridis Terhadap Penegasan Hierarki Peraturan Perundang-undangan di Indonesia Dalam Perspektif Stufen Theorie." Mercatoria. Vol. 9. Nomor 2. Desember. 